\title{
Tristão de ATAíde e OS tRÊS ANDRADES - O PROBLEMA DE DEUS
}

\author{
TRISTÃo de AtaídE AND tHE THREE ANDRADES - THE GOD'S PROBLEM
}

\author{
LEANDRO GARCIA RODRIGUES ${ }^{(*)}$
}

\begin{abstract}
RESUMO
Carta e literatura - uma sintomática relação. Este ensaio tem o objetivo de apresentar determinados aspectos da troca missivista entre Alceu Amoroso Lima (o Tristão de Athayde) com Oswald de Andrade, Carlos Drummond de Andrade e Mário de Andrade, ou seja, com os Três Andrades do Modernismo brasileiro. Nosso principal alvo analítico foi a problemática envolvendo a questão religiosa: o catolicismo e a prática da fé, o ateísmo ou o agnosticismo, a Igreja Católica - assuntos estes muito debatidos nesses epistolários, os quais sintetizo chamando de "o problema de Deus". Também serão discutidos alguns aspectos próprios e relativos do gênero epistolar, como sua natureza complexa e amorfa e sua importância, cada vez mais declarada, aos estudos literários e culturais, com particular atenção à Teopoética, aqui focalizada em relação ao nosso complexo processo modernista.
\end{abstract}

Palavras-Chave: Epistolografia. Religiosidade. Oswald de Andrade. Carlos Drummond de Andrade. Mário de Andrade. Alceu Amoroso Lima.

\section{ABSTRACT}

Letter and Literature, a symptomatic relation. This essay aims to present some specific aspects concerning the letter interchange between Alceu Amoroso Lima (Tristão de Athayde) with Oswald de Andrade, Carlos Drummond de Andrade and Mário de Andrade - the "Three Modernist Andrades" -, with a particular attention to the problematic discussion about the religious matter, the Catholicism itself and the practice of the faith, subjects widely discussed in this epistolary which I call "God's problem". Thus, we will also talk about some theoretical aspects of the Epistolary Genre itself, as well as its complex nature of performing of expressing, specially within the Brazilian modernist experience within the literary and religious studies - the Teopoetics itself.

KEYWORDS: Epistolography; Religiosity. Oswald de Andrade. Carlos Drummond de Andrade. Mário de Andrade. Alceu Amoroso Lima.

A área da Teopoética, ou Teopoesia para alguns, ainda é algo recente no Brasil, se a considerarmos tomando como referência os poucos anos de criação da ALALITE (Associação Brasileira de Literatura e Teologia), que tem dinamizado e ajudado na divulgação destes saberes por meio de encontros acadêmicos e publicações. Com ajuda de bons trabalhos acadêmicos em nível de Pós-graduação, temos percebido não apenas um maior interesse por esse campo de estudos por parte de pesquisadores e estudantes de diferentes áreas, mas também o surgimento de novas abordagens e hermenêuticas que obrigam a

(*)Professor de Teoria Literária da Universidade Federal de Minas Gerais.

Email: prof.leandrogarcia@hotmail.com 
nova visão e (re)avaliação dos mais diferentes cânones - literários e religiosos no que concerne ao "lidar" com o texto literário.

Mas se quisermos ser historicamente justos, devemos lembrar que a equipe da pesquisadora Salma Ferraz (UFSC) já vem fazendo isso, há muito tempo, bem antes da criação da ALALITE, haja vista o seu empenho na criação de um GT com esta temática no âmbito da ANPOLL (Associação Nacional de Pós-graduação e Pesquisa em Letras e Linguística). Eu mesmo tive o prazer de participar de um simpósio, por ela organizado, quando do congresso da ABRALIC (Associação Brasileira de Literatura Comparada) que ocorreu em 2002, na Universidade Federal de Minas Gerais. Ou seja, em muito Salma Ferraz e seus pesquisadores e orientandos antecederam a própria ALALITE.

Esta digressão se justifica apenas pela necessidade de se fazer historiografia, já que a memória é sempre importante, especialmente na proposta de uma área de investigação ainda jovem no Brasil. Por isso creio que os novos pesquisadores precisam conhecer um pouco desses relatos, a fim de perceberem que as decisões se dão após muita labuta, especialmente quando pensamos nas diferentes idiossincrasias do nosso meio acadêmico.

Na verdade, o que se vê é um trabalho e uma pesquisa "atravessados" pelos mais diferentes saberes, sempre na perspectiva do encontro com outras linguagens e abordagens, percebendo uma espécie de dissincronia do sincrônico, como proposto por Frederic Jameson em diversos dos seus textos e entrevistas. É esse sincrônico complexo dos estudos - tantos literários quanto teológicos - que se busca aproximar, nunca no sentido de descobrir e estabelecer verdades, ao contrário, valorizando justamente esta tal dissincronia que nos obriga a nos afastarmos de hierarquias (pré)estabelecidas no tocante ao diálogo teopoético. A teologia ilumina a literatura ou é a literatura que, sintomaticamente, representa o teológico? Não ouso responder a essa pergunta, mesmo porque o melhor é deixá-la sem resposta a nos remoer por dentro, a nos provocar pensamentos e possibilidades díspares no que concerne à natureza destes dois saberes.

Nessa perspectiva, proponho um diálogo entre quatro importantes personalidades do nosso mundo cultural: Alceu Amoroso Lima, Oswald de Andrade, Carlos Drummond de Andrade e Mário de Andrade. Vale, então, perguntar: qual a relação entre Amoroso Lima e Oswald de Andrade, Carlos 
Drummond e Mário de Andrade? Ou seja, como o próprio título deste ensaio adiantou, o que interliga os três Andrades do nosso Modernismo ao crítico literário e intelectual católico Tristão de Ataíde? Aproximações? Dissonâncias? Interesses mútuos? Ou apenas a boa e velha prática da correspondência?

Ao contrário do que muitos ainda acreditam e se confundem, esses três Andrades não foram parentes, são interligados pelo mesmo sobrenome apenas por uma grande e conhecida "coincidência literária”.

Devo lembrar também, em termos metodológicos, a declarada opção que tive pelo corpus epistolar, isto é, como especialista em Epistolografia - ciência literária que pesquisa cartas e correspondências - é a partir deste lugar que farei as minhas considerações críticas. Também é bom lembrar que, para isso, usarei os últimos livros que organizei, a saber: Drummond \& Alceu - Correspondência de Carlos Drummond de Andrade e Alceu Amoroso Lima (UFMG, 2014) - para as cartas trocadas entre este poeta e o crítico católico; Cartas de Esperança em Tempos de Ditadura - Frei Betto e Leonardo Boff Escrevem a Alceu Amoroso Lima (Vozes, 2015) e Correspondência Mário de Andrade e Alceu Amoroso Lima (EDUSP, 2016) - este último já em fase de produção, a ser lançado em outubro deste ano. Para as cartas entre Alceu e Oswald de Andrade, que estão inéditas, utilizei o arquivo do próprio Alceu Amoroso Lima, localizado na cidade de Petrópolis (RJ), sob a salvaguarda do Centro Alceu Amoroso Lima para a Liberdade (CAALL).

É importante ressaltar, também, que foi minha opção citar/transcrever longos fragmentos dessas cartas. Inclusive, há uma carta integral de Oswald de Andrade a Alceu, inédita, cujo conteúdo considero importante para que eu possa desenvolver minhas considerações crítica. Além disso, ainda não temos no Brasil uma boa tradição de pesquisa epistolográfica, se levarmos em consideração outros países como França e Inglaterra, onde tal sistemática vem sendo feita desde o século XIX. Por isso a minha opção em privilegiar, ao máximo, a fonte missivista dos respectivos autores analisados neste ensaio.

\section{COM OSWALD DE ANDRADE - “O DEus MoRTo”}

A julgar pela precária correspondência entre Alceu Amoroso Lima e Oswald de Andrade, podemos concluir que os mesmos nunca foram propriamente amigos epistolares, como ocorreu entre Drummond e Mário de 
Andrade com Alceu. Oswaldo, na verdade, não era um bom escritor de cartas, raramente as respondia, muito dificilmente as guardava, tanto que seu arquivo pessoal hoje depositado no CEDAE (Centro de Documentação Alexandre Eulálio), que pertence ao Instituto de Estudos da Linguagem da UNICAMP, é pobre no que diz respeito à correspondência passiva, isto é, ao que ele recebeu ao longo da vida. De Alceu, por exemplo, o arquivo registra apenas a presença de um telegrama.

Ao contrário, no arquivo do CAALL, sentimos uma maior preocupação de Alceu, seu senso arquivístico é exemplar, guardando e preservando tudo. Então temos nove (9) cartas de Oswald a ele endereçadas. Uma delas, me parece sintomática, e transcrevo-a integralmente:

São Paulo 8 de fevereiro de 1929

Tristão, meu caro crítico

Não posso ir ao Rio agora. O meu desejo, além de levar-lhe Serafim Ponte Grande, era pedir-lhe que centralizasse uma polêmica nacional, onde as grandes orientações se pudessem afirmar. Acabo de ver o Alexandre Correa que me disse estar pronto a entrar num debate sério que se fizesse aí, numa folha de circulação nacional. Ele e o professor Van Acker. Poderia ser no "O Jornal", organizada e distribuída pelo seu tato e pelo seu prestígio?

Essa ideia partiu das conversas que tive sobre ANTROPOFAGIA com Tasso da Silveira e Andrade Muricy ultimamente. O Tasso me disse: "Só podemos discutir por escrito". Eu aceitei. Combinamos que eu abrisse a questão. Eu começaria expondo seriamente os meus pontos de vista em cerrado ataque contra as duas correntes que, na minha opinião, estão procurando envenenar o Brasil - os católicos e os bolchevistas. O Tasso replicaria imediatamente. Há aqui um grupo marxista de apreciável cultura que falaria também. Que pensa você disso tudo? Eu só vejo uma possibilidade de realização - é você centralizar o debate e distribuí-lo, entrando nele está claro com a sua arguta inteligência $e$ infelizmente com o seu horroroso catolicismo. O Raul Bopp conversará detalhes.

Responda ao

\section{Oswald de Andrade}

Alameda Barão de Piracicaba 44-S. Paulo

P.S. O Mário só tem um destino - refugiar-se no folclore!

(CAALL / Série Correspondência Passiva / Pasta Oswald de Andrade - Texto Inédito) 
Pelas propostas feitas por Oswald de Andrade é-nos possível perceber as suas intenções e o porquê da sua aproximação de Alceu, já que esta é a primeira carta da correspondência entre eles. Fica claro também o tom declaradamente sarcástico e caricatural de Oswald, ao pedir que Alceu contribuísse na tal polêmica "com o seu horroroso catolicismo". Isto era próprio da verve de Oswald, conhecido pelo seu caráter demolidor em relação a tudo e a todos. Percebemos também a interligação com Mário de Andrade que, pelo ano (1929), já não mais tinha qualquer tipo de amizade com Oswald. A referência ao refúgio de Mário no folclore diz respeito à publicação de Macunaíma, no ano anterior, sabidamente um romance de caráter híbrido quanto às nossas tradições folclóricas amazonenses.

Podemos afirmar que com Mário Alceu trocou cartas, com Oswald trocou farpas. A respeito das diferenças entre estes dois Andrades, Alceu afirmou:

Essa dupla de Andrades, sem nenhum parentesco entre si, me parecia ser a própria expressão das duas faces da nova escola. Sem negar o valor intrínseco de cada um e sem querer excluir um pelo outro, Mário me parecia ser o lado construtivo do modernismo. Oswald, o seu aspecto demolidor, agitado e agressivo. Este chegara ao modernismo através da sátira, do espírito irreverente e visceralmente revolucionário, de tudo enfim que o torna hoje muito mais influente e expressivo para as novas gerações do fim do século XX, do que Mário. Este fora ao modernismo depois de um catolicismo convicto. De uma grande curiosidade intelectual. De uma procura da verdade com seriedade e esforço. Dois temperamentos tão opostos, que em pouco uma divergência de ordem moral, mais do que um simples mal entendido, os iria separar definitivamente. Nos dois, aliás, eu via a dupla vertente do modernismo. (LIMA, 1973, p. 92)

Certamente, a admiração de Alceu por Mário se dava por uma profunda identificação intelectual. Com a mentalidade que tinha, Alceu dificilmente aceitava uma proposta artística que surgisse de leviandades estéticas, de experimentalismos vazios e sem razão de existir. Neste sentido, Mário com a sua personalidade de scholar e pesquisador, encaixava-se perfeitamente nos critérios artísticos de Alceu. Era o artista estudioso, que atravessava o rio sem se esquecer da margem anterior.

Já Oswald era justamente o contrário, era o "anti-Mário", o “anti-Alceu". Oriundo de uma das famílias mais ricas de São Paulo, aproveitou o que pôde da fortuna que herdou do seu pai, principalmente esbanjando-a em diversas viagens que fez ao exterior. Paris era o seu destino mais certo. Oswald tinha 
uma personalidade demolidora, seus desafetos diziam que tudo o que tocasse automaticamente se destruía. De grande criatividade como polemista, desde cedo soube aproveitar bem os bons efeitos de um escândalo, de um bom bateboca literário. Quanto à sua visão de literatura, Oswald foi quem melhor vestiu o uniforme da vanguarda. Desde cedo se apaixonou pela noção de ruptura, de transgressão, de desafio à ordem cultural estabelecida.

Nesta perspectiva, a questão religiosa foi algo importante na sua vida, já que esta era vista como sinônimo de tradição, de passado, de valor familiar. Dificilmente, nesta visada vanguardista, Deus não tinha lugar, era preciso matar Deus de alguma forma e matar também tudo que lembrasse/representasse a presença divina, em especial, o binômio religião/religiosidade, vista por Oswald como um dos mais importantes sintomas do nosso atraso intelectual e cultural. Oswald não via uma forma de conciliar a herança religiosa com uma desprendida vida acadêmico-cultural, eram realidades que não dialogavam, o artista verdadeiramente livre não podia praticar e viver uma religião, particularmente a católica, fruto do nosso passado colonial e atrasado.

Décadas depois, em 1967, quando a equipe do diretor teatral José Celso Martinez Correa ensaiava a peça $O$ Rei da Vela, de Oswald de Andrade, montada no Teatro Oficina, um certo assistente de direção escreveu a Alceu pedindo um texto crítico sobre Oswald. Era Carlos Alberto Christo, ou simplesmente Frei Betto, que dividia a vida de frade dominicano com esta função na equipe do Oficina. Assim escreveu Frei Betto a Alceu:

\section{S. Paulo, 6 de agosto de 1967.}

Caríssimo Dr. Alceu

O Teatro Oficina de São Paulo pretende lançar em cartaz, no próximo mês de setembro, a peça "O Rei da Vela", de Oswald de Andrade. Nome tão importante em nossas letras, ficou esquecido durante muito tempo. É a primeira vez que a peça será encenada e, por isso, temos feito um trabalho sério em torno de sua preparação.

A família de Oswald de Andrade tem nos ajudado e, junto ao espetáculo, faremos uma exposição de suas obras e manuscritos inéditos. Por outro lado, lançaremos uma publicação contendo vários artigos sobre a peça e seu contexto histórico, religioso, filosófico, sociológico, moral etc.

Em vista de sua ligação com Oswald de Andrade, sobretudo em torno da Semana de Arte Moderna, consideramos imprescindível sua colaboração para a 
peça. Queremos lhe pedir, para que possamos publicar em nossos Cadernos, um artigo sobre a presença de Oswald de Andrade na literatura brasileira e o contexto histórico da peça "O Rei da Vela". Seria interessante também que o senhor discorresse sobre a visão religiosa que o autor demonstra nesta peça.

Gostaríamos de ter em mãos sua colaboração antes que este mês termine, pois assim ela nos serviria na montagem do espetáculo. Certos de sua atenção e disponibilidade, despedimos com um forte abraço.

Pelo Teatro Oficina,

Frei Carlos Alberto Christo OP

(apud RODRIGUES, 2015, pp. 61-64)

A peça $O$ Rei da Vela foi escrita em 1933, ainda sob o impacto políticosocial da Crise de 1929, sendo publicada apenas em 1937, mas nunca recebendo uma montagem durante a vida de Oswald de Andrade, permanecendo inédita até a montagem feita por Zé Celso Martinez Correa para o Teatro Oficina. O enredo explora os problemas advindos da dependência financeira, do sistema capitalista carnívoro que não livra ninguém e a submissão do homem moderno a este mesmo sistema. Através de personagens caricatos, Oswald critica a falta de moral da burguesia urbana e rural, bem como suas taras e desvios sexuais e comportamentais como um todo. Vale lembrar que, com essa iniciativa, Zé Celso resgatou a obra de Oswald de Andrade, na época envolta numa espécie de ostracismo e pouco pesquisada.

Curiosamente, Alceu Amoroso Lima foi duramente caricaturado por Oswald em $O$ Rei da Vela (Ato I), como se percebe nesta fala do personagem Abelardo I a respeito "de um crítico respeitado do Rio de Janeiro":

ABELARDO I: Bem! Depois não venha fazer vales aqui, hein. Eu também sei ser fiel ao sistema da casa. Vá lá. Redija! Não. Tome nota. Olhe. É uma carta confidencial. A um tal Cristiano de Bensaúde. Industrial no Rio. Metido a escritor. Redija sem erros de português. O homem foi crítico literário e avançado, quando era pronto... [...] Esse negócio de escrever livros de sociologia com anjos é contraproducente. Ninguém mais crê. Fica ridículo para nós industriais avançados. Diante dos americanos e dos ingleses. Olhe, diga isto. Que a burguesia morre sem Deus. Recusa a extrema unção. (ANDRADE, 2000, p. 53)

De fato, ignorando os antigos problemas que teve com Oswald, Alceu Amoroso Lima escreveu uma pequena crônica - "O Deus Perdido" - publicada nos Cadernos do Oficina, mas que também saiu na Folha de São Paulo (caderno 
Ilustrada), em 28 de setembro de 1967 e mais tarde (1971) foi compilado no livro de memórias Companheiros de Viagem. Neste texto, Alceu fez uma dramática narrativa do seu tenso convívio com Oswald de Andrade. Embora longa, a nota é interessante:

Minhas relações com Oswald de Andrade sempre foram distintas e tumultuosas, como convinha a dois temperamentos totalmente opostos. Poucas vezes nos encontramos pessoalmente e outras tantas nos mimoseamos reciprocamente com sarcasmos periódicos, sem maior maldade e muito menos rancor. Conhecemonos de longe, quando publicou Os Condenados, em 1922, que recebi com entusiasmo, no meu rodapé dominical de O Jornal. Pouco mais tarde, a propósito da "Poesia Pau Brasil" e do "primitivismo", nos desentendemos. Fui encontrá-lo pessoalmente, pela primeira vez, quase vinte anos depois, em 1941, ao fazer uma série de conferências em A Gazeta, de que iria resultar o livro Estética Literária. Estava modestamente, como qualquer ouvinte comum, na fila dos cumprimentos, depois da última conferência: "Sou o Oswald de Andrade. Você continua a ser um liberal", ainda ouço suas palavras e relembro seu sorriso gaiato. Mas o nosso encontro dramático foi poucas semanas antes de sua morte. Sabendo-o gravemente enfermo, fui visitá-lo, sem prevenir. Ao me ver, começou a chorar convulsivamente, abraçando-me. Eram trinta anos de vida literária brasileira, seus encontros e desencontros, que se reviam em face do irreparável. Era todo o nosso passado, nossas brigas, nos entusiasmos, nossas transformações íntimas, nossas melancolias, que se juntavam naquele abraço convulso da modesta casinha em que habitava, com sua última esposa e seu casal de filhos, adolescentes. Encontramo-nos ainda duas outras vezes. O tema, a que voltava invariavelmente comigo, era o religioso. Logo no primeiro encontro me interpelou: “Tristão, diga-me por favor, por que é que você se converteu?" E ouvindo longamente minhas palavras, tinha o olhar distante e insatisfeito. $\mathrm{O}$ problema religioso sempre foi nele uma obsessão. Seu ódio à Igreja e seus sarcasmos constantes contra a fé eram a sua forma de amar a Deus! Quem não compreende esse paradoxo não compreenderá jamais essa alma trabalhada sempre por uma angústia profunda, por um desesperado protesto contra as injustiças da sociedade e por uma irreparável nostalgia do Deus perdido. (LIMA, 1971, pp. 256-257)

“O problema religioso sempre foi nele uma obsessão”. Interessante ressaltar que Alceu Amoroso Lima fez essa observação para os três Andrades. Indo mais longe: Alceu detectou este "problema” em relação a vários escritores da sua geração como Augusto Frederico Schmidt, Cornélio Pena, Murilo Mendes, Jorge de Lima, Lúcio Cardoso, Otávio de Faria e tantos outros. Em relação ao problema de Deus nos três Andrades, Drummond foi cético, Oswald foi destrutivo e Mário foi um mal resolvido. Todavia, mesmo quando negavam Deus, de uma certa forma (paradoxalmente), estavam a afirmá-Lo.

Infelizmente, as outras cartas enviadas por Oswald a Alceu não citaram mais esta problemática, ao contrário, falavam de questões puramente literárias 
e também de problemas quando, em 1942, o escritor carioca Múcio Leão publicou uma carta de Oswald de Andrade a Alcântara Machado, na qual citava suas (de Oswald) brigas com Mário de Andrade. Rapidamente, o autor de Macunaíma se sentiu pessoalmente ofendido com a atitude de Oswald, cabendo a Alceu "apagar as chamas deste incêndio", interferindo junto a Múcio Leão e ao Correio da Manhã para que se retratassem publicamente.

Entre o Deus morto, o poeta vivo e o crítico literário estava a linha tênue que os interligava - a religião - tida como certeza inquestionável para Alceu e problema (e até escárnio) para Oswald. Todavia, um escárnio sintomático que, mais do que negava, indiretamente afirmava e confirmava a importância desta temática para ambos. Não apenas para eles, mas para toda uma geração de artistas e intelectuais envolvidos no processo de modernização cultural do Brasil.

\section{COM CARLOS DRUMMOND DE ANDRADE - “A PAZ NÃO É DESTE MUNDO”}

Alceu e Drummond "se conheceram" através de Mário de Andrade, que os "aproximou” epistolarmente, isto é, propôs que Drummond escrevesse a Tristão de Ataíde, o então crítico literário mais importante na longínqua década de 20 do século passado. A correspondência entre ambos durou de 1929 até 1982 num total de 132 documentos (cartas, telegramas, postais, fotos e bilhetes) trocados.

Dividi toda esta narrativa epistolar em três fases, já que os debates mudaram muito de acordo com a época da troca missivista. A primeira fase, que foi de 1929 a 1934, foi profundamente marcada pelas dúvidas existências e religiosas de Drummond, todas expostas em tais cartas, relato único deste poeta conhecido pela timidez e dificuldade de falar sobre si próprio. Mas nas cartas era diferente...

Mais uma vez, o problema de Deus aflora como problema da religião, que Drummond vê em Alceu a pessoa certa para expor e tentar compreender, como se percebe nesta carta de 24 de janeiro de 1929, que o poeta enviou ao crítico:

Sou dos maus, dos piores católicos que há por aí. Talvez seja uma crise da mocidade, não sei, entretanto sinto pouca disposição para crer, e um contato extremamente doloroso que tive com os jesuítas me afastou ainda mais da religião. Fiz mal, talvez, em confundir a religião com os seus ministros... ou não é possível julgar aquela a não ser através destes? De qualquer maneira, admiro e quase que invejo os que como V. deram uma solução definitiva a esse problema religioso que nós carregamos como uma ferida. Quem sabe se ainda não chegarei 
até lá? Por enquanto vejo tudo escuro dentro de mim, e a vida sem compromissos me solicita terrivelmente.

"Sinto pouca disposição para crer", esta é uma afirmação deveras interessante que marca não apenas a pessoa de Drummond, mas de uma boa parte da sua geração, fortemente marcada pelos ideais do Positivismo e do Cientificismo, ideologias estas vindas da Europa e que se impregnavam na mentalidade culta brasileira com uma força realmente considerável.

"Fiz mal, talvez, em confundir a religião com os seus ministros". Outra questão de relevância: o problema de Drummond, inicialmente, foi com a instituição Igreja Católica e não necessariamente com a religião em si. O poeta de Itabira foi aluno de dois colégios religiosos - o Colégio Arnaldo, de Belo Horizonte (MG), dirigido pelos padres verbitas; e também do Colégio Anchieta, em Nova Friburgo (RJ), dirigido pelos jesuítas. Deste último, Drummond foi expulso por "insubordinação mental", fato este digno de ser ressaltado, pois naquela época ser expulso de um colégio religioso não era uma vergonha apenas para a criança, mas para toda sua família, sendo motivo de críticas na pequena sociedade da qual participava.

Entretanto, em cada pessoa, tais acontecimentos provocam e projetam diferentes sensações, cada um somatiza de maneira diferente, fazendo surgir revoltas e separações, o que se percebe na relação de Drummond com a religião. Para o poeta, Deus estava morto? Certamente não. Mas a sua Igreja sim, considerando aqui o catolicismo como religião tradicionalmente adquirida, ainda mais na perspectiva de Minas Gerais. Neste afã, Alceu tentou entender a celeuma drummondiana, e esta compreensão era algo comum a ele Alceu, que também fora um cético e fora convertido ao catolicismo graças à ação epistolar de Jackson de Figueiredo. E, carta a Drummond, a 1 de fevereiro de 1929, assim o crítico responde:

Sou um terrível pesquisador de almas. Amo as almas como um avarento ama as moedas: não por caridade (ou ainda não, pois a lição da cruz é que é preciso amálas por amor e só por amor) mas por avidez do mistério, por curiosidade, por insatisfação do que já sei, do que já vi, do que já despachei. V. fala na ferida que levam os que como v. não creem ou não sabem que creem. Essa ferida é já um pouco de amor à Fé. Os que nada esperam dela, nem ao menos tem a noção da ferida, a suspeição de uma ausência, a intuição de que há qualquer coisa além do mundo que nos cerca. E no mais, a Fé é também uma ferida. É mesmo a maior das feridas humanas. Veja como nós, católicos, representamos o coração de Cristo ferido de amor aos homens. Pois bem, a Fé é uma ferida quase crônica. 
Creia, é sentir toda a falta do mundo em torno de si, se bem que será também sentir o equilíbrio profundo em tudo. Mas será um equilíbrio que se conquista dolorosamente, pelos caminhos sempre sombra, pelas "portas estreitas". Enfim, não quero posar de pregador leigo. A Fé não se incute, conquista-se. E como é um alargamento e não uma restrição, como é uma plenitude, só mesmo o caminho interior pode levar a ela ou tornar a ela.

Ao afirmar que "A Fé não se incute, conquista-se", Alceu dá uma ideia da sua práxis intelectual entre os artistas céticos: conquistar pelo convencimento, não pela obrigatoriedade. Assim, o crítico alimentou uma forte relação de argumentação e contra-argumentação com diferentes correspondentes a respeito da existência ou não de Deus, da importância ou não da fé e da religião, como se percebe neste seu diálogo epistolar com Carlos Drummond de Andrade.

Alceu analisa o estado de Drummond pela ótica de um recém convertido (sua conversão se deu em 1928) ainda empolgado com o Mistério, inebriado e absorto na mística da transformação integral da criatura que reconhece o seu Criador, por isso sente nessa "ferida" drummondiana a presença silenciosa e ruminante da fé: a ferida como presença calada de Deus e, paradoxalmente, um

silêncio que arrebenta em questionamentos e inquietações, um estranhamento consigo mesmo e com a sua própria história pessoal. Interessante perceber que Alceu não compactua com aquela noção messiânica de que a fé é sinônimo de paz interior e sossego para a alma, como esperava Drummond, mas trata-se de uma experiência que revoluciona o ser por dentro, tirando-o de uma condição de conforto. Ou seja, a fé é algo que revoluciona por dentro, provoca inquietações, tremores na existência. Para Alceu, a fé é busca incessante de um porquê, de uma razão, de um para quê buscar a Deus, ou seja, um movimento constante e tenso, às vezes desnorteador, nunca pacífico e calmo, como muitos pensam, como o próprio Drummond pensava. Por isso "a Fé não se incute, conquista-se”, entendendo por conquista uma ação desafiadora e, às vezes, desconfortável. Como era de se esperar, Alceu não convenceu Drummond com tais propostas, tanto que o poeta retrucou, em 1 de março de 1929, com esta espécie de carta-desabafo:

\section{Caro Tristão}

Sou-lhe muito grato pela sua bela e generosa carta, que guardo com carinho entre os meus papéis. Só um trecho dela é que me perturbou: aquele em que você dá a entender que não encontrou a paz na religião, porque a paz não é deste mundo. Mas então não sei o que se deva procurar na religião. Se ela não é uma paz máxima e consoladora, uma dissolução de todos os ímpetos, revoltas, 
inquietações, não seria preferível continuar do lado de cá, sem nenhuma certeza superior e sem nenhuma esperança?

O problema é que o "lado de cá" é por natureza fragmentado, rachado, incerto, cético, e tais estados não preenchem o costumeiro vazio próprio da condição humana, a nossa busca pelo eterno, pelo infinito, por aquilo que fica e dura. É justamente este entre-lugar, profundamente marcado pela tensão (como qualquer entre-lugar), que corrói e traz incerteza e ceticismo, possibilidades e não certezas, desconfianças e o sentimento inquieto e incômodo de que algo a mais existe, esta espécie de metafísica perturbadora e tentadora do eu lírico. Tais aspectos críticos são deveras sintomáticos na poesia de Carlos Drummond de Andrade - uma busca por uma razão, por um sentido maior para a vida e apara a existência como um todo. Drummond desabafou, na mesma carta, o seu não entendimento para a razão de Deus (e da própria fé) existir:

Você talvez ache covarde o meu pensamento; ou, no mínimo, comodista. Veja, mas em todo caso é humano. A minha pobre humanidade só poderia procurar na ideia religiosa o apaziguamento do espírito, o termo das lutas com o mundo e comigo mesmo (estas sobretudo). Não consigo compreender aqueles que dando tudo o que têm de melhor a Deus (como você) dele não recebem a paz. Mas não posso deixar mais um dia sem resposta as suas linhas tão cautas, quanto cheias de coisas. Não posso também dizer muita coisa. Estou positivamente exausto. [...] Que problema tremendo esse que você toca. O problema da felicidade!

Tentemos aproximar tais questionamentos por uma outra ótica de cálculo. Para o Alceu ainda agnóstico, a felicidade era encontrada nas conquistas práticas do engenho humano, forte, com aquele destemor incentivado pelas diversas teorias cientificistas que pulularam na transição dos séculos XIX-XX, das quais ele sempre se viu como um fruto ideológico, bem como toda a sua geração. Para o Alceu convertido, as forças do engenho humano continuavam com o seu devido valor, porém acrescido de uma mística envolvente que lhe dava transcendência, ou seja, o existir só tinha razão se fosse direcionado a Deus, a verdadeira e única felicidade/realização do Homem, a razão última de todas as coisas. Como a correspondência demonstra, Drummond não concordou com esta equação, tanto que respondeu, em outubro do mesmo ano:

Eu sou um pobre homem sem orientação e sem coragem para optar, e se reconheço os meus erros não me animo a dar-lhes combate. Se eu lhe contasse a minha vida moral!... Sou fraco, fraquíssimo. Todos os dias as mesmas quedas 
silenciosas e um desgosto profundo, imenso de viver, com o medo de morrer que é o mais triste de todos os medos.

Parece mesmo que "tremor na alma" perseguiu o poeta, especialmente nesta fase inicial da sua obra e do seu fazer poético. Entretanto, em entrevistas dadas nos últimos anos da sua vida, Drummond continuava com este ceticismo em relação à fé, em relação à religião, num claro agnosticismo que marcou o seu pensamento, sempre lembrado pelos biógrafos e críticos da sua obra. Seria este o seu lado "gauche"? Ou o "gauche", mais do que um simples lado, seria todo um estado de vida?

Perguntas sempre suscitadas pela problemática religiosa que envolve artistas e intelectuais, muito disso percebido na intensa onda de conversão religiosa de escritores quando da Ação Católica francesa, particularmente no início do século XX.

Como se percebe, o problema de Deus é complexo, muitas vezes sem solução, apenas sintomas de fragmentação do sujeito num século XX por si só fragmentado e ávido de um sentido para o existir, para o estar no mundo.

\section{COM MÁRIO DE ANDRADE - “A CIVILIZAÇÃo VAI MUdAR, TRISTÃO”}

A correspondência entre Mário e Alceu está em vias de ser publicada, numa edição por mim organizada, preparada pelo Instituto de Estudos Brasileiros da Universidade de São Paulo (IEB-USP) e publicada em coedição entre a EDUSP e a editora da PUC-Rio. São ao todo cinquenta e seis (56) documentos (cartas, telegramas e bilhetes) trocados ao longo de dezenove anos, entre 1925 e 1944.

Tais documentos foram todos transcritos a partir dos respectivos originais, assim depositados: as cartas de Mário a Alceu estão no Centro Alceu Amoroso Lima para a Liberdade, em Petrópolis (RJ). O outro lado da correspondência as cartas de Alceu a Mário - está sob os cuidados do Instituto de Estudos Brasileiros (IEB - USP).

Discutiram sobre um pouco de tudo nesta correspondência: literatura, criação, vida literária, livros e... religião. Este último tópico, na minha opinião, é o que tem de mais original e substancioso nesta troca missivista entre ambos. Inclusive, tais cartas ajudam a compreender este "buraco" na biografia de Mário 
de Andrade, já que a maioria dos seus biógrafos insistem em considerá-lo um ateu. Discordo radicalmente desta classificação comumente empregada ao autor de Pauliceia Desvairada. Acho-a pobre demais, carente de uma boa argumentação biográfica, enfim, simplista. Nesta carta de 14 de julho de 1929, Mário dá boas informações sobre o seu estado religioso:

\section{S. Paulo, 14-VII-29}

Alceu,

Talvez devido às amarguras, eu tenha exagerado um pouco o meu estado de espírito de agora. Nada de fundamental se modificou em mim e se você me permite chamar de "catolicismo" que sempre tive, continuo tendo. Não sei nem me deitar nem levantar sem essa carícia pra Deus e os nossos intermediários que é a reza. É certo que estou no momento atual numa irritação muito forte. Mas não é contra o Catolicismo. É principalmente contra os católicos. Os porquês são muito longos e já são vinte e quatro horas deste meu último dia de férias. Mas você também há-de sentir que existe hoje uma "moda católica" que, profícua ou não pros almofadinhas dela, há-de irritar com nitidez um espírito como o meu. Minha produção si tem sido especialmente acatólica, pode ter certeza que é pela discrição sensibilizada com que me sinto na impossibilidade de jogar uma coisa pra mim tão essencial e tão elevada como a religião dentro dessas coisas tão vitais, terrestres e mundanas como as artes. Por isso apenas me limitei a respeitar uns gritos de sincero religioso e amarguras que saíram em versos e prosa minha. Na Pauliceia o "Religião", a imitação do salmo de Davi e o que a circunda no "Carnaval Carioca", as páginas amargamente irônicas sobre o catolicismo tradicional da família Sousa Costa no "Amar, Verbo Intransitivo" e quase que só. [...]

Ora, percebemos aqui uma questão semelhante a que Drummond partilhara com Alceu: Deus não é de todo um problema, mas a religião sim, a Igreja sim, os católicos sim. Só que tudo isso é vivido de forma meio híbrida, não se separa tão cartesianamente os mesmos, provocando uma plêiade de questionamentos e até sofrimentos internos e pessoais. $\mathrm{E}$ isto foi assaz sintomático em relação a Mário de Andrade, digo mesmo que foi uma das suas principais "feridas na alma", para usar a mesma expressão aludida por Drummond.

Inclusive, Mário nunca escondeu a sua religiosidade - católica - nem mesmo em parte da sua produção poética, como ele próprio lembrou nesta carta a Alceu. O seu poema "Religião", publicado em Pauliceia Desvairada, assim começa: "Deus! Creio em Ti! Creio na tua Bíblia! / Não que a explicasse eu mesmo, / Porque a recebi das mãos dos que viveram as iluminações! [...]”. Isto sem dizer do seu "Carnaval Carioca", cujos seguintes versos são bem elucidativos: 
Aleluia!

Louvemos o Criador com os sons dos saxofones arrastados,

Louvêmo-Lo com os salpicos dos xilofones nítidos!

Louvemos o Senhor com os riscos dos recorrecos e os estouros do tantã,

Louvêmo-Lo com a instrumentarada crespa do jazz-band!

Louvêmo-Lo com os violões de cordas de tripa e as cordeonas imigrantes,

Louvêmo-Lo com as flautas dos choros mulatos e os cavaquinhos de serestas ambulantes!

Louvemos $O$ que permanece através das festanças virtuosas e dos gozos ilegítimos!

Louvêmo-Lo sempre e sobre tudo! Louvêmo-lo com todos os instrumentos e todos os ritmos!... [...]

(ANDRADE, 1993, p. 169)

Salta aos olhos o hibridismo poético praticado por Mário de Andrade, uma vez que faz um amálgama interessante da tradição dos salmos bíblicos com aspectos da cultura tais como o jazz, o samba, instrumentos musicais, a tradição da música negra etc. Isto é, uma espécie de antropofagia cultural muito defendida por eles modernistas, especialmente aqueles alinhados às propostas de renovação de Oswald de Andrade no seu Manifesto Antropófago. Além da sua produção artística e ficcional, Mário já dera algumas pistas em textos críticos, especialmente nas suas crônicas jornalísticas, acerca da sua (tensa) relação com Deus e com a religião. É o que percebemos em "Começo da Crítica", na qual podemos ler:

Creio em Deus, tenho essa felicidade. E jamais precisei de provas filosóficas para crer. Deus é uma espécie de constância do meu ser (não se dará o mesmo com todos?...), eu O sinto na ponta do meu nariz. Mas se trata de uma entidade verdadeiramente sobre-humana, que a minha inteligência não consegue alcançar, de uma grave superioridade silenciosa. Isso, aliás, se percebe muito facilmente no sereno agnosticismo em que descansa toda a minha confraternização com a vida. Deus jamais não me prejudicou a minha compreensão dos homens e das artes." (ANDRADE, 1993, p. 13)

E não foi essa a única vez que Mário falou, tão abertamente, acerca do seu sentimento e da sua práxis religiosa, encarando Deus como um ser onisciente, onipresente e, acima de tudo, necessário ao ser humano, aspectos estes que contribuem bastante para repensarmos o seu "ateísmo" tão afirmado e 
confirmado por alguns críticos quando analisam a sua obra, como já dito anteriormente.

Alceu sempre se mostrou sensível a esta dimensão do seu amigo paulista, tanto que falou e discorreu muito sobre ela em diferentes crônicas e depoimentos que fez sobre Mário de Andrade, como no artigo "Dez anos depois":

Creio que perdeu a fé explícita depois de uma infância profundamente religiosa. Mas conservou a vida inteira uma fé implícita, a marca indelével da Presença inefável que uma vez por todas tinha entrado, na infância, em seu coração. E por isso, escrevia a Manuel Bandeira, que repudiava todos os poemas da Pauliceia Desvairada, exceto o poema "Religião". E esse era justamente aquele em que fazia o contraste veemente entre a falsa religiosidade mundana das "missas das onze" e a figura do Cristo Crucificado, da religião verdadeira. Nas discussões de ordem religiosa, entre companheiros, quando a maioria se mostrava anticlerical ou antireligiosa, ele sempre tomou a defesa do Cristo e da Fé Cristã. Podia, no íntimo, sentir o vazio ou viver lutando contra o ceticismo ou protestando contra a "indignidade dos cristãos" de que fala Mauriac - mas sempre teve, no fundo da consciência o problema de Deus como polo norte de sua vida ardentemente vivida. (LIMA, 1971, pp. 45-50)

Alceu é bem claro na sua tese: Mário "conservou a vida inteira uma fé implícita, a marca indelével da Presença inefável que uma vez por todas tinha entrado, na infância, em seu coração”. E isto era maior do que a própria concepção de uma religião, de um credo, de uma instituição. Ou seja, o religare era mais importante do que a religião, e Deus estava acima disso tudo já que é esta "Presença inefável” e misteriosa, porém presente. Sem querer brigar ou abrir um debate mais raivoso com o amigo, Alceu responde a Mário, nesta carta de 17 de julho de 1929:

Mário

[...] Não quero, porém, abusar de sua confiança e acanhar e preocupar a quem talvez no momento não deseja ou possa dedicar tempo a esses problemas. Eu mesmo sei que não tenho qualidade, e sobretudo capacidade alguma para tratar disso, e que, no seu caso, o trabalho terá de ser interior, com a graça especial de Deus que até hoje nunca lhe faltou de todo. Abstenho-me, por isso, de entrar diretamente no que na carta tem de mais geral, reservando-me para o fazer algum dia, ou já, se você julgar oportuno.

Você bem sabe que nós, católicos nãa de moda mas de convicção e de drama interior, não podemos nunca nos recusar a debater esses problemas que são, para nós, de vida ou morte. 
Aqui Alceu aborda uma questão que considero importante e crucial nessa correspondência - ser "católico não de moda mas de convicção e de drama interior”. Isso era algo realmente problemático para aquela geração, marcada no âmago pelas correntes ateias do Positivismo e do Cientificismo arraigados que tanto se desenvolveram no Brasil, desde o final do século XIX e que tinha se reforçado no início do século XX. De fato, era difícil para um intelectual declarar-se crente em Deus naquele contexto, pois seria sectarizado ou mesmo excluído do convívio daqueles que não compactuavam com tais ideologias. Além desta problemática "mais prática”, havia aquela de natureza mais ontológica, isto é, não é simples converter-se, não é simples crer numa realidade não materializada, não palpável, sentida apenas na perspectiva do Mistério e da entrega pessoal ao ato de crer, considerando a fé como uma espécie de ofertório pessoal a este mesmo Mistério.

Décadas depois, após um longo e sintomático hiato na correspondência, Mário e Alceu voltaram a discutir esta mesma problemática, com Mário se expressando de forma mais ácida e profundamente cético em relação à necessidade da religião na sua vida, mas sempre afirmando a sua crença em Deus, de forma subjetiva, íntima e procurando "sentir" Deus numa perspectiva toda pessoal, até mesmo um tanto ontológica, como se percebe nesta carta a Alceu, em 17 de junho de 1943:

Sim: o Catolicismo é muito maior que você e vocês todos católicos. Mas o Catolicismo tem esse, pelo menos, perigo de ser além de uma Ideia, uma religião. Vocês têm de pôr a ideia em ação. E é dentro desta Ideia em ação que com todos os padres que cercam você, bem ou mal intencionados, úteis ou nefastos; com todos os fiéis que admiram você e aceitam preliminarmente as suas pregações; com todos os moços safados de carne que se torturam no espírito e a que você dará suavização e o sabor católico de uma rápida paz; com todas as boas ações, atos de caridade ocultos, esmolas escondidas que você possa fazer: é dentro dessa Ideia em ação que eu não aceito você. Que você me irrita. Que você me afasta porque não quer me atingir. Você e a "religião", a coletividade terrestre que guarda a Ideia católica. [...]

A civilização vai mudar, Tristão. A Civilização Cristã chamada, e que não sei se algumas vezes $V$. não confunde um bocado com Cristo, está se acabando e vai ser um capítulo da História. Tão lindo como o dessas igualmente nobilíssimas civilizações da Antiguidade, o Egito, a China, a Grécia. Com a Cristã nós demos um passo a mais, apenas um passo a mais do amilhoramento terrestre do homem e da sociedade humana. Se nem tudo foi pra melhor, o todo foi incontestavelmente pra melhor. E a civilização que vem ainda há-de ser fatalmente um passo a mais, e um todo melhor. Tudo isto nada tem que ver com o 
outro mundo. Nem eu sei nem quero a morte da Igreja imortal e o desaparecimento da religião nem a sempre por demais próxima chegada do Anticristo. Mas não haverá o perigo pra muitos e pra você, de preferir a Igreja a Deus?.Eu não ignoro não os perigos dos meus argumentos para o meu paracatolicismo em que me debato. Serão argumentos do Diabo. Ou serão argumentos do orgulho. Mas eu quero bater a uma porta mas essa porta não pode se abrir porque os que estão lá dentro não podem interromper o Te-Deum. Então eu solto um grande grito pra Deus me escutar. E como eu "quero" que Ele me escute, Ele me escuta. Mas ainda não pude saltar o grande grito e me sinto sozinho. Porque os que deviam vir a mim porque eu não vou a eles, não vêm até mim. E eu não sei si há-de haver tempo para eu saltar o grande grito.

Mário chega a ser duro e um tanto inflexível com Alceu, fazendo de sua carta uma espécie de testamento espiritual a respeito das suas conturbadas convicções religiosas. Foi justamente nesta acidez espiritual que Mário viveu a fé nos seus últimos anos de vida, vindo a falecer em fevereiro de 1945, mas deixando em testamento o seu desejo de ser sepultado com o hábito da Ordem Terceira Carmelita, da qual era membro com profissão solene de votos.

Além destas questões, Mário de Andrade usa constantemente o termo "para-catolicismo" para designar uma espécie de "catolicismo paralelo", ou seja, um sentimento católico que ainda permanecia nele próprio devido à sua formação e criação. Todavia, era uma simples permanência, quase como uma "lembrança”, e não como "prática de um credo". Isso ele sempre deixa bem claro nas suas cartas não apenas a Alceu, mas a todos os seus correspondentes que tocavam nesse assunto. E novamente toca no mesmo problema que o atormentou por muito tempo: "A Civilização Cristã chamada, e que não sei se algumas vezes V. não confunde um bocado com Cristo”, isto é, a complicada simbiose entre Cristo e a Igreja, entre a fé e a profissão de um credo, entre seguir ou não uma religião.

Por seu lado, mais conciliador e tentando compreender as idiossincrasias do amigo, Alceu deu o seu ponto de vista em relação aos problemas e dramas aludidos por Mário, tanto que respondeu ao amigo:

Petrópolis - 24-junho [1943]

Sim, meu caro Mário, é sempre tempo de você soltar "o grande grito". A despeito da sua confessada "incompreensão", a despeito das suas raivas pessoais, a despeito de tudo o que sua carta revela contra nós e contra mim, particularmente, estou mais junto de você do que você pensa. [...] 
Em que é que ficamos? Você se contradiz a cada passo. Aliás, como toda alma "com raiva". Você diz que o Cristianismo "morreu". Uma forma de Cristianismo sim. Mas não o Cristianismo. Na civilização de amanhã, que será socialista como a de ontem foi liberal, o lugar da Igreja e do Cristianismo será o mesmo. Não mais como na Idade Média, mas numa posição tão inabalável, no fundo, como então. Eu mais que você tenho raiva dos que vivem "cantando Te Deum".

É a defesa de um crente o que se esperava de uma personalidade como a de Alceu Amoroso Lima que, a essa altura, não era apenas o editor-chefe da revista A Ordem e diretor do Centro Dom Vital, mas também o presidente de toda a Coligação Católica Brasileira, uma mega estrutura organizacional dos órgãos e entidades que impulsionavam a vida pastoral do catolicismo brasileiro, sempre alinhado com a ortodoxia doutrinal e com a própria hierarquia da Igreja.

Para finalizar, cito aqui o fragmento de uma crônica - "Mário de Andrade e o Catolicismo" - publicado no livro Companheiros de Viagem, na qual Alceu conclui as suas observações críticas sobre o problema religioso na obra e na pessoa de Mário de Andrade:

E como Mário não era homem de fingir o que quer que fosse, o que está nas suas cartas estava na sua alma. E o que estava na sua alma é que crepita nas cavernas interiores da sua obra. A religião é o elemento central mas invisível na obra de Mário de Andrade. E essa é, a meu ver, a chave do seu segredo. E a religião católica. Não apenas uma religiosidade vaga ou convencional ou herdada ou de mero desejo de crer. O que houve sempre nele foi a luta incessante entre uma crença em Deus e em Cristo inabalável, e a impossibilidade de se curvar ante às exigências morais e sociais do catolicismo e, acima de tudo, uma irritação contra os católicos, contra a "pseudocivilização cristã", contra a Igreja, em geral. (LIMA, 1971, pp. 50-59)

Desta forma, concluímos esta abordagem crítica, mas estamos longe de esgotar as considerações sobre esta tão complexa problemática que afligiu (e ainda aflige!) uma considerável parcela da nossa intelectualidade, fenômeno este vividos em todos os tempos, mas com considerável ênfase nas primeiras décadas do século XX.

Os três Andrades do Modernismo não ficaram imunes a isso. Viveram e problematizaram das mais diferentes formas, seja pela negação, pelo ceticismo ou pela caricatura. Mas não se livraram deste mesmo problema.

Encontraram em Alceu Amoroso Lima o destinatário à altura de tais debates, alguém com quem podiam não apenas compartilhar as inquietações 
mas, acima de tudo, digladiar ideologias e possibilidades, provocando novas hermenêuticas e instaurando um sintomático debate de alto nível, travado nas inúmeras cartas trocadas ao longo de décadas a fio, especialmente com Carlos Drummond de Andrade, numa amizade epistolar que durou mais de cinquenta anos.

Não apenas cartas, mas importantes testemunhos de uma época conturbada, de almas conturbadas e sedentas por encontrarem um sentido ontológico da existência, do estar no mundo, tendo Deus como o eixo de um problema longe de ser facilmente resolvido.

\section{SUAS CARTAS, NOSSAS CARTAS}

Muitas são as possibilidades epistemológicas levantadas por uma correspondência; as cartas, longe de serem apenas trocas de informações e dados, são verdadeiras possibilidades de criação estilística e debate ideológico. São verdadeiros "laboratórios de ideias", para usar a expressão de Vincent Kaufman, crítico literário francês e um especialista deste gênero textual.

Numa outra visada mais historiográfica, a correspondência também serve para iluminar e mostrar as particularidades - erros e acertos - do próprio movimento modernista brasileiro, através dos filtros de Alceu Amoroso Lima e dos três Andrades aqui analisados, elucidando suas lacunas, conquistas, limitações, dúvidas, questionamentos, obras, avanços e retrocessos. Novamente, recorro a Júlio Castañon Guimarães:

As cartas dos modernistas ao mesmo tempo que apresentam a efervescência de mudanças em vários aspectos culturais, históricos e políticos, apresentam também aqui e ali sinais de que estavam inseridas em um nível de mudanças em sua própria conformação. Basta pensar no quanto o desenvolvimento do correio propiciou o aumento da frequência da correspondência. No entanto, também se poderia supor que a precariedade das comunicações telefônicas tornava estas infrequentes e obrigava a que se continuasse a empregar a correspondência como forma de comunicação. [...] A correspondência dos modernistas é o último grande momento dessa forma dentro da literatura brasileira, isto tanto pelas possibilidades de relacioná-la diretamente com as obras do movimento e pelo que oferecem em termos de conhecimento do próprio gênero epistolográfico, quanto por se ter constituído como espaço em que de modo fundamental se elaborou parcela importante de um movimento decisivo na cultura brasileira. (GUIMARÃES, 2004, p. 42) 
Não são apenas levados e trazidos pelos Correios \& Telégrafos, mas são “cartas pensamenteadas”, usando a expressão de Mário de Andrade numa carta a Manuel Bandeira, em 19 de março de 1926. E digo mais: são cartas semânticas e cheias de múltiplas possibilidades interpretativas e agentes de transformação do cânone da nossa própria história literária (e por quê não da historiografia?). Entre o palco e os bastidores, a criação e a publicação, o público e o privado, a correspondência vai preenchendo diferentes lacunas da nossa vida literária, possibilitando a compreensão de determinados estilos e intenções, determinadas obras e os caminhos de sua criação, bem como ajuda na decifração de inúmeras problemáticas biográficas e pessoais que envolvem o universo pessoal dos artistas. Isto foi possível perceber na questão levantada do "problema religioso" vividos pelos três Andrades do nosso Modernismo.

Por isso, suas cartas - nossas cartas. Aliás, a quem pertence uma carta? Ao remetente? Ao destinatário? Ao futuro leitor? Não respondo, apenas especulo. Em "Razões mais profundas", ensaio introdutório à correspondência de Carlos Drummond de Andrade e Alceu Amoroso Lima, Marcos Antonio de Moraes fornece outras possibilidades para a pesquisa epistolográfica:

A correspondência dificilmente produz a ilusão de uniformidade de um "retrato" estático dos interlocutores. Fragmentos discursivos, orientados por interesses comuns entre os carteadores, sofrendo derivas imprevistas na condução dos assuntos, resultam, quando reunidos, em um testemunho autobiográfico instável. A autorrepresentação no espaço da carta modifica-se ao longo dos dias, traduzindo o dinamismo do ser. Surpreende-se na correspondência a subjetivação em processo, território movediço, onde coexistem valores e ideários obstinados, reavaliações da experiência e flagrantes contradições. [...] Em contraste com o empreendimento (auto)biográfico, sujeito aos artifícios retóricos totalizantes e teleológicos, a correspondência, essencialmente fragmentária, altamente alusiva, marcada pela instabilidade na fixação de um perfil e pela multiplicidade de figurações do sujeito, exige instrumental analítico particular, aberto para as percepções das peculiaridades de cada grupo de missivas, em um viés de interpretação de natureza fenomenológica.

É o que vejo ao analisar o triplo conjunto epistolar entre os Andrades do Modernismo brasileiro com Alceu Amoroso Lima, recortando este mesmo conjunto na direção dos problemas relacionados à fé e a Deus debatidos ao longo destas cartas. Tal fato me obriga a repetir, de forma clara e objetiva: suas cartas, nossas cartas. 


\section{REFERÊNCIAS}

ANDRADE, Mário de. Aspectos da Literatura Brasileira. São Paulo: Martins/MEC, 1972.

Cartas a Manuel Bandeira. Prefácio e notas de Manuel Bandeira. Rio de Janeiro: Org. Simões, 1958.

Mário de Andrade escreve Cartas a Alceu, Meyer e Outros. Rio de Janeiro: Editora do Autor, 1968.

O Empalhador de Passarinho. Belo Horizonte: Itatiaia, 2002.

Vida Literária. São Paulo: EDUSP/HUCITEC, 1993.

\& ANDRADE, Carlos Drummond de. Correspondência Mário de Andrade e Carlos Drummond de Andrade. Ed. Preparada por Silviano Santiago. Rio de Janeiro: Bem Te Vi, 2003.

\& BANDEIRA, Manuel. Correspondência Mário de Andrade e Manuel Bandeira. Ed. Preparada por Marcos Antonio Moraes. São Paulo: IEB/EDUSP, 2000. ANDRADE, Oswald de. O Rei da Vela. Rio de Janeiro: Editora Globo, 2000.

AZZI, Riolando. História da Igreja no Brasil - Terceira Época 1930-1964. Petrópolis: Vozes, 2008.

FERNANDES, Cléa Alves de Figueiredo. Jackson de Figueiredo - Uma Trajetória Apaixonada. Rio de Janeiro: Forense Universitária, 1989.

GALVÃO, Walnice Nogueira. “À Margem da Carta”. In: Desconversa (Ensaios Críticos). Rio de Janeiro: Editora da UFRJ, 1998.

GENNETE, Gérard. Palimpsestes - La Littérature au second degré. Paris: Seuil, 1987.

GOMES, Ângela de Castro. Essa Gente do Rio... - Modernismo e

Nacionalismo. Rio de Janeiro: Fundação Getúlio Vargas Editora, 1999.

GUIMARÃES, Júlio Castañon. Contrapontos: notas sobre correspondência no modernismo. Rio de Janeiro: Fundação Casa de Rui Barbosa, 2004.

Distribuição de Papéis: Murilo Mendes escreve a Carlos Drummond de Andrade e a Lúcio Cardoso. Rio de Janeiro: Fundação Casa de Rui Barbosa, 1996.

KAUFMANN, Vicent. L’equivoque Épistolaire. Paris: Éditions de Minuit, 1990. LIMA, Alceu Amoroso. Affonso Arinos. Rio de Janeiro: Civilização Brasileira, 1922. A Estética Literária e o Crítico. Rio de Janeiro: Livraria Agir Editora, 1954.

Companheiros de Viagem. Rio de Janeiro: José Olympio, 1971. 
Memorando dos 9o. Rio de Janeiro: Editora Nova Fronteira, 1984.

Vozes, 1973.

Memórias Improvisadas - Diálogos com Medeiros Lima. Petrópolis:

Notas para a História do Centro Dom Vital. Rio de Janeiro:

Educam/Paulinas, 2001.

\& FIGUEIREDO, Jackson de. Correspondência - Harmonia de

Contrastes, Tomos I e II. Rio de Janeiro: Academia Brasileira de Letras, 1991.

LOPEZ, Telê Ancona. Táxi e Crônicas no Diário Nacional. São Paulo: Duas Cidades, 1976.

MORAES, Marcos Antônio.(org.). Correspondência Mário de Andrade \& Manuel Bandeira. São Paulo: EDUSP, 2000.

Orgulho de Jamais Aconselhar - A Epistolografia de Mário de

Andrade. São Paulo: EDUSP/FAPESP, 2007.

"Razões mais profundas". In: RODRIGUES, Leandro Garcia. Drummond \&

Alceu - Correspondência de Carlos Drummond de Andrade e Alceu

Amoroso Lima. Belo Horizonte: UFMG, 2014.

RODRIGUES, Leandro Garcia. Alceu Amoroso Lima - Cultura, Religião e Vida Literária. São Paulo: EDUSP, 2012.

Cartas de Esperança em Tempos de Ditadura - Frei Betto e Leonardo Boff escrevem a Alceu Amoroso Lima. Petrópolis: Vozes, 2015.

Correspondência Mário de Andrade \& Alceu Amoroso Lima. São

Paulo: EDUSP/PUC-Rio, 2016. [no prelo]

Drummond \& Alceu - Correspondência de Carlos Drummond de

Andrade e Alceu Amoroso Lima. Belo Horizonte: UFMG, 2014.

. Uma Leitura do Modernismo - Cartas de Mário de Andrade a Manuel

Bandeira. Dissertação de Mestrado. Rio de Janeiro: Pontifícia Universidade Católica do Rio de Janeiro, 2003.

SANTIAGO, Silviano. "Suas cartas, nossas cartas". In: ANDRADE, Carlos Drummond de \& ANDRADE, Mário de. Carlos \& Mário - Correspondência completa entre Carlos Drummond de Andrade e Mário de Andrade. Organização e pesquisa iconográfica de Lélia Coelho Frota. Rio de Janeiro: Bem-Te-Vi, 2002.

Recebido em 16/05/2016 Aprovado em 15/o6/2016 